\title{
Economic Impact of COVID-19 in Asia, Europe, North Africa and the Middle East
}

\author{
Nancy del Rocio Flores Hinojosa, Liliana del Carmen Morillo Acosta \\ Administrative Sciences Department, Central University of Ecuador, Quito, Ecuador \\ Email:nrflores@uce.edu.ec,1morillo@uce.edu.ec
}

How to cite this paper: del Rocio Flores Hinojosa, N., \& del Carmen Morillo Acosta, L. (2021). Economic Impact of COVID-19 in Asia, Europe, North Africa and the Middle East. Open Journal of Business and Management, 9, 2640-2651.

https://doi.org/10.4236/ojbm.2021.95145

Received: July 15, 2021

Accepted: September 27, 2021

Published: September 30, 2021

Copyright $\odot 2021$ by author(s) and Scientific Research Publishing Inc. This work is licensed under the Creative Commons Attribution International License (CC BY 4.0).

http://creativecommons.org/licenses/by/4.0/

\begin{abstract}
This study aims to present a description of the economic impact of COVID-19 in Asia, Europe, North Africa and the Middle East. This pandemic outbroke in the city of Wuhan in China, spreading to approximately 213 countries and territories around the world and is still ongoing. We are particularly interested in investigating the economic outlook for COVID-19. This document uses data from scientific contributions published in the Dimensions research academic database; starting from the fact that this situation is an event in development, still. In addition, the bibliometric analysis tools of science from this Dimensions platform are used. In addition, VOSviewer software was used to build and visualize bibliometric science networks. To explore this issue in depth, we divided the economic impact into several regions, that is, the Chinese economy, the Central Asian economies, the South Asian economies, the Southeast and West Asian economies, the European economies, the North African, North African economies, Middle East. With all intention, the document avoids the information that is handled in the American continent, since it is a much more accessible and current knowledge in our geo-economic contact. This scientific contribution concludes that epidemic situations seriously affect economies around the world. The basic reasons behind such severity are labor immobility, reduced productivity, supply chain disruption, decreased exports, uncertainty, etc. This study is of interest for companies and legislators to estimate and plan current and post-pandemic situations.
\end{abstract}

\section{Keywords}

Economic Management, Human Resource, Productivity, Supply Chain, Exports, Imports, COVID-19

\section{Introduction}

COVID-19 belongs to the family of viruses found in animals and can be trans- 
ferred to humans (Augustine, 2020). COVID-19 was discovered in the favored Wuhan, China; this is a city of 11 million inhabitants and a highly industrialized, educational and scientific zone in China (Ayittey, Ayittey, Chiwero, Kamasah, \& Dzuvor, 2020). This fateful event originated in a market where animals and birds are sold. The initial host for the virus was the bat, which also contains other viruses from the same family, such as Ebola, AIDS, and rabies. But bats weren't the only animals sold in Wuhan. However, it is thought that it may have also infected other animals and birds (Augustine, 2020). The first cases were reported on December 31, 2019. Most of the deaths recorded in the Chinese town of $\mathrm{Hu}-$ bei where Wuhan is located (Baker, Bendix, \& Frias, 2020).

The virus spread so fast throughout China that China's industries and institutions were immediately shut down. The city of Wuhan is being called the city of ghosts as millions of people remained locked up as a precaution not only in the city of the outbreak but also in dozens of cities across the country. Business activities have been closed throughout China. The barrier to business activities has caused a scandal in the Chinese economy. This uproar can cause a big gap towards China's goal of becoming the world's largest economy. In addition, it can cause a drop in the economy of countries that have a commercial interest with China (Ayittey et al., 2020).

COVID-19 is identified when the person has symptoms. It takes at least 5 days for a person to show symptoms of the virus. Initial symptoms consist of a dry cough, fever, and a feeling of being unwell. It also includes dry lungs and tiredness in other parts of the body. The nature of the virus is that it spreads very fast. Recently, the mortality rate of the virus registered is $20 \%$ (Augustine, 2020).

So far, COVID-19 has killed more than 446,522 people and infected more than $8,282,815$ people worldwide. At least 213 countries outside of China have reported cases. The most affected countries after China are South Korea, Italy, Japan and Iran, which not only suffer health problems but also a disturbance in the economy (Baker et al., 2020). According to the date given by Chinese doctors, $20 \%$ of cases are fatal and need hospitalization, while the other $80 \%$ are those that are mild and can be cured through their immune system if it is strong. Most fatal cases are in older people (Bizaer, 2020).

The virus is spread by person-to-person contact. Like other viruses, namely the flu and coughs, the virus is easily spread by droplets and carried from place to place. When people contact them, they contract the virus. The only protection measure from the virus is to stay clean by washing well with soaps and keeping germs away through frequent use of disinfectant (Augustine, 2020). However, a cure has not yet been found. No medicine has been developed for the Ebola virus and AIDS. Most doctors say that the cure depends on a person's immunity. Most cases of the virus are mild, while the rest needs to hospitalization (Baker et al., 2020).

It is not the first time that China has faced such a situation. SARS broke out in 2002-2003 and affected China and countries around the world. Initially, it was 
neglected, but then it spread to 37 countries. More than 8000 people were affected and 750 of them died. It became one of the most dangerous viruses in the history of mankind (Augustine, 2020). According to a survey, COVID-19 is spreading six times faster than SARS. But, China's development in 18 years has made China stronger to cope with the result and it is believed that it can make China stronger than ever (Bociaga, 2020).

Since the last 40 years, the Chinese economy has grown splendidly. China currently has a GDP of $\$ 13.6$ trillion, making China the second largest economy in the world. China also holds the title of the world's largest economy by purchasing power parity, holder of foreign exchange reserves, manufacturer and producer of goods (Mancha Navarro \& Gallo Rivera, 2015). China's dream of being an economic superpower has led China to become the largest US trading partner (Ayittey et al., 2020).

\section{Materials and Methods}

As material for this research, the Dimensions database and academic research directory is used. This platform differs from Scopus, as it is an open access platform and has very similar potentialities and tools for bibliometric analysis of science. Dimensions are inclusive; captures all research results, greatly increasing your analysis options. As of December 2019, Dimensions contained more than 106 million posts, about $30 \%$ more than comparable databases.

The other computational tool used in this research was VOSviewer. This is a software tool for building and visualizing bibliometric networks. These networks can include, for example, individual journals, researchers or publications, and can be built on the basis of citation, bibliographic coupling, co-citation, or co-authorship relationships. VOSviewer also offers text mining functionality that can be used to build and visualize co-occurrence networks of important terms drawn from a body of scientific literature. The functionality of this tool can be condensed into two fundamental aspects:

1) Creation of maps based on network data. You can create a map based on a network that is already available, but it is also possible to build one of the networks. The VOSviewer can be used to build networks of scientific publications, scientific journals, researchers, research organizations, countries, keywords, or conditions. The elements of these networks can be connected by links of co-authorship, co-occurrence, citation, bibliographic coupling or co-citation. Files can be used to build a Web of Science, Scopus, Dimensions, PubMed, RIS, or Crossref JSON data.

2) View and explore maps. VOSviewer provides three visualizations of a map: the network visualization, the overlay visualization, and the density visualization. The zoom and pan feature that allows you to explore a map in full detail, which is essential when working with large maps containing thousands of items.

The information that was detected in the academic research platform Dimensions, was under the search criteria "Economic impact of COVID-19". The in- 
formation detected allowed the generation of Figure 1, using the bibliometric tools of the Dimensions platform itself. This data package was exported in (.ris) format to be able to process it in the VOSviewer software and thus perform text mining. Text mining generated the map of phrase terms with the highest co-occurrence, which is shown in Figure 2. At this point, the research focuses on a qualitative and reflective analysis of the information detected, developing a discussion structure of the analyzed documents.

number of publications in each research category. (Criteria: see below)

11 Medical and Health Sciences

14 Economics

16 Studies in Human Society

15 Commerce, Management, Tourism an...

17 Psychology and Cognitive Sciences

08 Information and Computing Sciences

09 Engineering

13 Education

05 Environmental Sciences

12 Built Environment and Design

18 Law and Legal Studies

06 Biological Sciences

01 Mathematical Sciences

21 History and Archaeology

07 Agricultural and Veterinary Sciences

03 Chemical Sciences

04 Earth Sciences

02 Physical Sciences

20 Language, Communication and Culture

10 Technology | 24

22 Philosophy and Religious Studies | 20

19 Studies in Creative Arts and Writing | 12

Source: https://app.dimensions.ai

Exported: June 25, 2021

Criteria: Text - 'Economic impact of COVID-19' in title and abstract; Publication Year is 2020 or 2021

(c) 2021 Digital Science and Research Solutions Inc. All rights reserved. Non-commercial redistribution / external re-use of this work is permitted subject to appropriate acknowledgement. This work is sourced from Dimensions ${ }^{\circledR}$ at www.dimensions.ai.

Figure 1. Number of publications related to the impact of COVID-19; detected in the academic research catalog Dimensions. Source: Data, detected and processed in the Dimensions academic research platform.
229

201

172

159

148

123

120

114

91

72

52

51

43

\section{7}

20




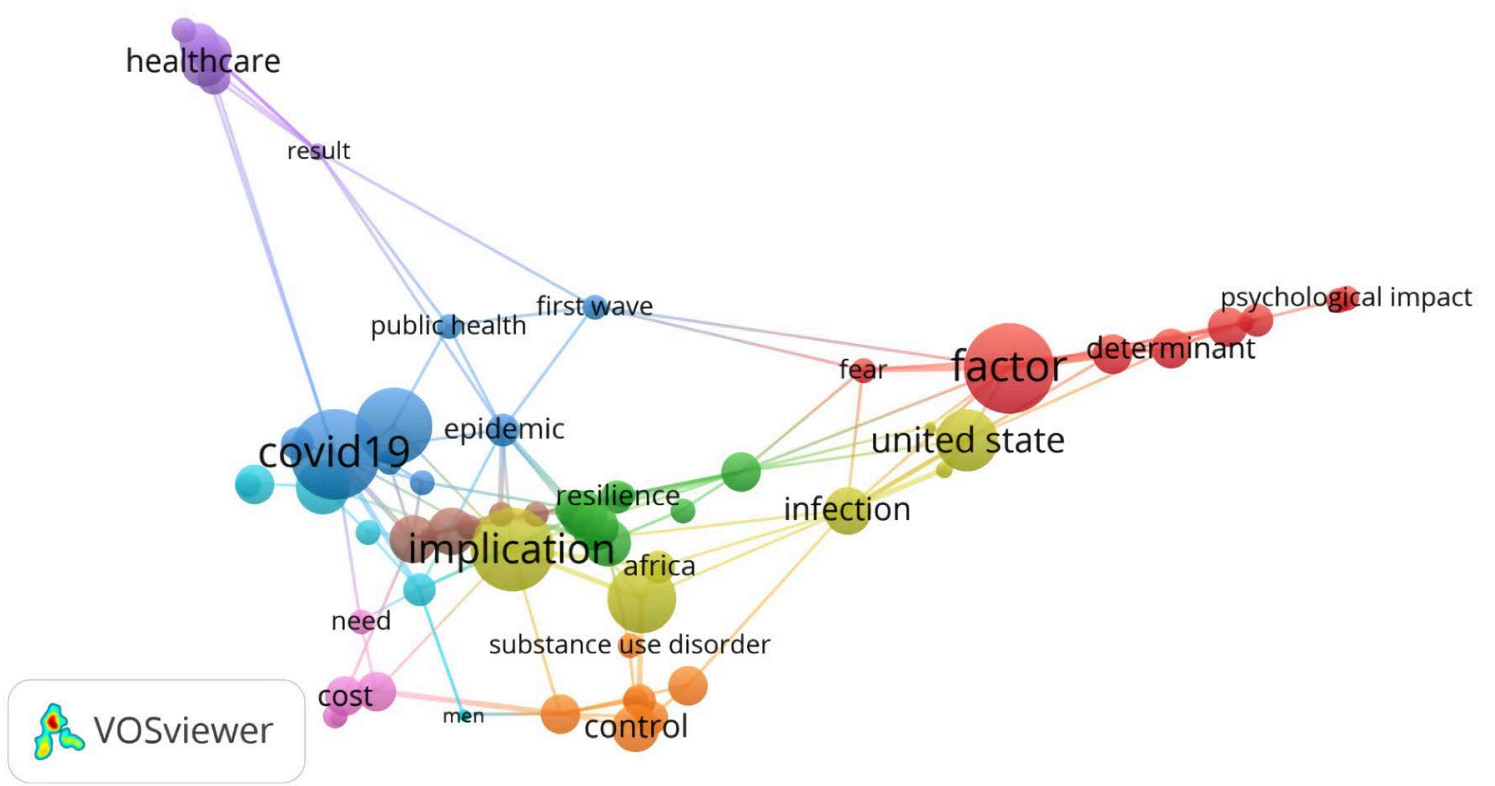

Figure 2. Map of phrase terms with the highest co-occurrence, obtained in the text mining process on the investigations detected in Dimensions. Source: Data, detected and processed in the Dimensions academic research platform and processed in VOSviewer.

\section{Results and Discussion}

\subsection{Biometric Synopsis of the Information Detected under the Declared Search Criteria}

Obviously, research on this issue began with the emergence of the pandemic, this incident has spread very quickly and with great intensity to many areas of life. Like the epidemiological crisis that is COVID-19, the first busiest line of research is that of health research and medical analysis. The second most investigated aspect is the economic impact that this health crisis has generated. Another highly researched aspect is the social impact of this unprecedented crisis. Figure 1 highlights the most developed research areas in relation to this topic. This document focuses on the second most researched aspect of this pandemic, which is the economy. Specifically, the economic impact of COVID-19 is in Asia, Europe, North Africa and the Middle East. In the aforementioned figure, the number that precedes the research topic to the left of the graph refers to the number of sources and the number that is reflected to the right of the graph, just after the blue bars, refers to the number of sources. Observing these results, it can be concluded that this research is perfectly justifiable, sustainable and timely, in the current academic environment.

The information detected was processed in the VOSviewer software. This is a computational tool that allows the construction and visualization of bibliometric networks. These networks can include, for example, individual journals, researchers or publications, and can be built on the basis of citations, bibliographic coupling, co-citation or co-authorship relationships. VOSviewer also offers text mining functionality that can be used to build and visualize co-occurrence net- 
works of important terms extracted from a body of scientific literature.

Figure 2 shows a correlation map of the most recurrent or most used terms in the scientific contributions detected. This map of terms was made using text mining on the abstract and keywords of the investigations detected in the database and academic research catalog Dimensions under the search criteria established in the materials and methods section of this document. In this term map the intensity of co-occurrence can be observed, which is represented by the diameter of the spheres; the connectivity of the terms that is represented by the lines; and the colors represent the analysis blocks.

\subsection{The Economic Impact of Covid-19}

To achieve the objectives of this study, we divided the economic impact into six dimensions, namely, the Chinese economy, the Central Asian economies, the South Asian economies, the South-East and West Asian economies, the European economies, the South-East Asian economies, North Africa and the Middle East. This research focuses on these regions and areas of the world, because the information that is handled in South America, on these regions, is less common and more limited; thus, providing a greater originality and opportunity for penance and scope to this scientific contribution.

\section{Chinese economy}

The COVID-19 episode is likely to affect China's economy within two quarters, said Stephen Roach, a professor at Yale University. He also reported that the effect of isolation and limitations on movement has practically stopped the Chinese economy. In addition, Beijing began forcing large closures and isolating urban areas in late January, ruining the production line and the monetary balance. However, Professor Roach believes that the Chinese government will not back down in efforts to contain the COVID-19 outbreak despite there being a significant monetary effect. He advised the Chinese authorities to maintain a strategic distance from other counterparts (Cascais, 2020).

The ongoing COVID-19 outbreak in China has had notable effects on organizations and businesses. Below is the information detected in the investigative academic directory, mentioned above (Chatzky \& McBride, 2020; Chrysoloras, Dendrinou, \& Brambilla, 2020).

- Industrial productivity has fallen by $13.5 \%$ in January and February.

- The urban unemployment rate increased to $6.2 \%$ in February.

- Retail sales fell 20.5\% year-on-year in January and February.

- Fixed investment decreased by $24.5 \%$, compared to growth of $5.4 \%$.

- The production of services also fell $13 \%$ in January and February.

- GDP falls $13 \%$ during January and February.

- Exports are down $17.2 \%$ in January and February.

\section{Central Asian Economies}

The geographical limits of Central Asia range from the Caspian Sea (west) to Mongolia (east), and from Afghanistan and Iran (south) to Russia (north). Ac- 
cording to 2019 statistics, the Central Asian economies have a population of $72,960,000$, a (nominal) GDP of $\$ 300$ billion, and a GDP per capita of $\$ 4000$. Countries like Kazakhstan, Kyrgyzstan, Tajikistan, Turkmenistan, and Uzbekistan are very close to mainland China. China invests heavily in Central Asian countries and increases its dominance through business establishment and infrastructure development. China increased the volume of trade between Central Asian countries by more than $\$ 30$ billion (Citroner, 2020; Fulton, 2020).

China's strategic motives for establishing relations with the Central Asian economies are to gain access to raw materials and build a route to countries with large oil reserves. These countries sell about $90 \%$ of their exports to China in the form of oil and raw materials. Investments in the aforementioned plans are also significant for China to be an economic superpower (Fulton, 2020). It is established that Beijing will increase its participation in these economies to obtain the maximum benefits (Navarro, 2006). Therefore, the Central Asian states are representing their strategic interest in the Chinese energy sector (Inman, 2020).

Central Asia surprises many by accepting large sums of Chinese investment. In 2017, China made an investment of $\$ 304.9$ billion with its partners in transportation, communications, technology and trade (Laruelle, 2018). Central Asia has a very low level of progress in the health sector and they are more vulnerable to the epidemic like COVID-19. Countries like Uzbekistan and Tajikistan have to stop flight operations to China and begin to proactively screen those who have just returned from China, this causes a very damaging impact on BRI1 and the projects and investments under this umbrella (Citroner, 2020).

South Asian economies

The South Asian economies are made up of Pakistan, India, Bangladesh, Sri Lanka, Bhutan, Nepal, and the Maldives. In Bangladesh they invested in energy and transport projects, in Sri Lanka they invested in a seaport, but their main investment is in Pakistan under CPEC2 (Miankhel, 2019). They invested more than $\$ 60$ billion in Pakistan for the development of roads, energy projects, technology transmission and economic zones to establish industries and make Pakistan's infrastructure more advanced to facilitate both countries (Newey \& Gulland, 2020).

After the COVID-19 outbreak, Bangladesh stops working on ongoing projects with Chinese workers and engineers. Similarly, in Pakistan the pace of projects will slow down, however the government has not yet ordered a halt to the projects. In Sri Lanka, a 14-day quarantine is mandatory for people coming from mainland China, and restrictions are also imposed on Chinese workers to stay in construction sites or dormitories. Work at Port City in Colombo continued at a very slow speed because most of the staff returned to China to celebrate the new year and have not yet returned (Miankhel, 2019). Similarly, the inauguration of the tallest communication tower and other construction companies in Sri Lanka are also delayed due to the immobility of Chinese workers (Nguyen, 2020).

Most South Asian countries have canceled the visa issuance service for Chi- 
nese works and tourists. About 3000 employees from China were working on a $\$ 2.5$ billion energy project in Bangladesh. At the port of Payra, about 2/3 of the employees returned to China to rejoice in the new year, but unfortunately, they have not returned yet. Similarly, approximately 980 Chinese works that are working on a $\$ 3.5$ billion Padma multipurpose bridge have yet to return (Nguyen, 2020).

\section{Southeast and West Asian economies}

This geographical belt links several countries such as Indonesia, Singapore, Malaysia, Brunei, Myanmar, Mongolia, etc., and has a huge trade, trade and investment relationship with China, as the Chinese invest billions of dollars in many projects, in these countries under the BRI (Raga, 2020). But the recent COVID-19 outbreak in mainland China, the industrial city of Wuhan, created disastrous implications for Chinese workers and supplies (Roach, 2020).

Among the total number of tourists who came to Myanmar, Mongolia, Thailand, Vietnam and Cambodia, 1/5 is made up of Chinese citizens. The economic influence of COVID-19 tends to affect economies that have adjacent relationships with China in the form of business, investment, or tourism (Shepard, 2020). These countries sell approximately $1 / 6$ of their exports to China (Valero, 2020).

In Indonesia, progress on the Sumatra hydroelectric plant is about to halt due to unavailability of Chinese personnel, as Indonesia restricts flights to/from China. The $\$ 6$ billion high-speed rail project between Jakarta and Bandung is also on hold (Raga, 2020). Vietnam will also be affected because its economy is highly dependent on Chinese products (Roach, 2020). Meanwhile, the economies of Singapore and Hong Kong also face serious threats of slower growth (Shepard, 2020).

\section{European economies}

European countries are interconnected with each other to support their economy as a whole, yet COVID-19 brings recession to their economies. In the current epidemic situation of COVID-19, the ECDC3 published a report describing that the underlying risk for European countries is changing from moderate to high. It is also explained in the report that the situation is quite complex and requires strong coordination. The effect of COVID-19 and the possible ways to limit this type of situation seriously harms European economies. Therefore, the OECD4 lowers the 2020 growth estimate for the euro zone from $1.1 \%$ to $0.8 \%$; however, for the year 2021, the growth targets are set at $1.2 \%$ (Weerasekara, 2020).

Italy, as the nation hardest hit in the eurozone by COVID-19, declared a $€ 3.6$ billion aid package to resolve the outbreak. The Swiss government is also providing financial support from a $\$ 10$ billion aid package to control COVID-19. Confirmed cases in Spain increased from 2000 to 7753 and deaths doubled from 136 to 288. Cyprus declared financial support worth 700 million euros (3\% of its GDP) to support companies and workers. Germany closed its borders with France, Switzerland, Austria, Luxembourg and Denmark (Weinland \& Liu, 
2020).

\section{North African and Middle Eastern Economies}

According to economists, the economic impact of COVID-19 in the GCC5 and MENA6 region could be much greater than originally anticipated (Wright, 2020). Considering the speed and magnitude of the outbreak across the world and the MENA region, the epidemic has serious consequences for the global economy and regional economies, particularly the oil-exporting states, resulting in a downward revision. The Middle East could lose billions of dollars in tourism and hospitality, commerce, retail, real estate and Expo 2020. It will cause a long-term impact on the economies of the MENA and GCC countries, destabilizing their businesses, financial institutions and much more (Yellinek, 2020).

Iran, the most affected Middle Eastern country, has around 9000 confirmed cases and more than 350 deaths. Countries like Saudi Arabia, Bahrain, United Arab Emirates, and Oman also have multiple cases of infection. Nigeria faces a serious threat of recession because it maintains intense trade relations with China by occupying the position of the largest buyer of Chinese products among the African region (Zhu, 2020).

A serious decline in GDP is expected, that is, 2.1\% (2020) from 2.8\% (2019) in the MENA region, and $1.7 \%$ (2020) from 2.5\% (2019) in the GCC region. Such a huge decline is due to the slowdown in demand for energy (oil, gas and petrochemicals) in China, the reduction in Chinese tourism flows, the disruption of supply chains for Chinese products and the rapid fall in prices of oil (Zogg, 2019).

\section{Conclusion}

COVID-19, a virus, which affects the world population, puts pressure on the global health system and which the WHO declares as a pandemic. The current and subsequent days have seen the world economy come to a standstill as nations mobilize to block and stop further spread. The resulting effects are shocking as global supply chains are disrupted and business activities are forced to collapse. To address this situation and save themselves from an economic recession, countries around the world declared huge tax incentives. But the current health crisis and the ensuing economic recession appear to be far from over. Although it is not the first time that the world has faced such a situation, previously we encountered SARS-2003, MERS-2012, Ebola-2013, etc. However, COVID-19 is being regarded by the IMF as the worst pandemic that could lead the world economy into the deepest depression since the Great Depression.

Therefore, this study aims to showcase an overview of COVID-19 that is triggered from Wuhan, now spreading to approximately 213 countries and territories around the world and is still ongoing. More specifically, we are interested in exploring the economic outlook for COVID-19. For that purpose, we use data from articles published online and media reports, as the epidemic situation is still unfolding. To make this study more meaningful, we evaluated information 
from various economies, namely China, Central Asia, South Asia, West and Southeast Asia, Europe, North Africa, and the Middle East. The findings of the study conclude that COVID-19 seriously affects the global economy and the causes behind such severity are the immobility of the workforce, the reduction of productivity, the interruption of the supply chain, the decrease in exports.

However, this research focuses on an area that could be assessed for further inspection. Additionally, based on the pandemic currently facing health systems and economies, the study may be valuable in helping policymakers and business owners estimate and plan for current and post-COVID-19 circumstances. The study also has some limitations, for example, since it relies on articles published online and media reports, it can be very useful to explore these relationships empirically. But right now, when the pandemic still continues, it is important to be vigilant and watch out for the consequences.

\section{Conflicts of Interest}

The authors declare no conflicts of interest regarding the publication of this paper.

\section{References}

Augustine, B. D. (2020). Coronavirus Impact on GCC Economies Could Be Much Bigger. Gulf News.

https:/gulfnews.com/business/coronavirus-impact-on-gcc-economies-could-be-muchbigger-1.70099912

Ayittey, F. K., Ayittey, M. K., Chiwero, N. B., Kamasah, J. S., \& Dzuvor, C. (2020). Economic Impacts of Wuhan 2019-nCoV on China and the World. Journal of Medical Virology, 92, 473-475. https://doi.org/10.1002/jmv.25706

Baker, S., Bendix, A., \& Frias, L. (2020). Mapping the Coronavirus Outbreak. Business Insider.

https://www.google.com/amp/s/www.businessinsider.com/china-wuhan-virus-map-citi es-countries-spread-infected-2020-1\%3famp

Bizaer, M. (2020, March 16). Economic Paralysis: Coronavirus Slams Brakes on China Economy. AlJazeera.

Bociaga, R. (2020, March 11). Is COVID-19 Eroding China's Influence in Southeast Asia? The Diplomat.

Cascais, A. (2020, March 3). Coronavirus Infects Africa's Economy. Deutsche Welle. https://amp.dw.com/en/coronavirus-infects-africas-economy/a-52620528

Chatzky, A., \& McBride, J. (2020, January 28). China's Massive Belt and Road Initiative. Council on Foreign Relations.

https://www.cfr.org/backgrounder/chinas-massive-belt-and-road-initiative

Chrysoloras, N., Dendrinou, V., \& Brambilla, A. (2020, March 15). Europe Widens Virus Lockdown, Moves to Limit Economic Damage. Bloomberg. https://www.bloomberg.com/news/articles/2020-03-15/europe-lockdown-spreads-as-n ations-move-to-limit-economic-damage

Citroner, G. (2020, March 6). Here's What Older at Risk People Should Know about Corona Virus. Healthline. 
https://www.healthline.com/health-news/what-older-people-with-chronic-conditionsneed-to-know-about-covid-19

Fulton, J. (2020, March 5). The Impact of Coronavirus on Gulf Economies. Atlantic Council.

https://atlanticcouncil.org/blogs/menasource/the-impact-of-coronavirus-on-gulf-econ omies/

Inman, P. (2020, February 14). Will Coronavirus Outbreak Derail the Global Economy? The Guardian.

https://www.theguardian.com/news/2020/feb/10/will-the-coronavirus-outbreak-derailthe-global-economy

Laruelle, M. (2018, January 19). China's Belt and Road Initiative and Its Impact in Central Asia. Voices on Central Asia.

https://voicesoncentralasia.org/chinas-belt-and-road-initiative-and-its-impact-in-centr al-asia/

Mancha Navarro, T., \& Gallo Rivera, M. T. (2015). La influencia de la economía en la popularidad y en los resultados electorales de los partidos políticos españoles: Una investigación empírica. Documentos de Trabajo, No. 7, 37 p.

Miankhel, A. (2019, June 29). Why Central Asia Chooses Chinese Investment. East Asia Forum.

https://www.eastasiaforum.org/2019/06/29/why-central-asia-chooses-chinese-investme nt/

Navarro, T. M. (2006). ¿Existen ciclos político-económicos en España?: Un análisis del periodo 1977-2004. Paper presented at the La política económica en tiempos de incertidumbre. La Política Económica en Tiempos de Incertidumbre, 25-50.

Newey, S., \& Gulland, A. (2020, March 15). What Is Coronavirus, How Did It Start, and Could the Outbreak Grow Bigger? Telegraph.

https://www.telegraph.co.uk/news/0/what-coronavirus-how-spread-uk-global-pandem icl

Nguyen, T. (2020, February 13). The Economic Fallout of the Coronavirus in Southeast Asia. Carnegie Endowment for International Peace.

https://carnegieendowment.org/2020/02/13/economic-fallout-of-coronavirus-in-south east-asia-pub- 81070

Raga, S. (2020, February 5). Economic Vulnerabilities to the Coronavirus: Top Countries at Risk. Overseas Development Institute.

https://odi.org/en/insights/economic-vulnerabilities-to-the-coronavirus-top-countriesat-risk/

Roach, S. (2020, February 28). The Coronavirus Outbreak May Have a Two-Quarter Hit on China's Economy. CNBC.

https://www.cnbc.com/amp/2020/02/28/coronavirus-may-hit-chinas-economy-for-2-q uarters-stephen-roach-says.html

Shepard, W. (2020, February 29). Coronavirus Outbreak puts Belt and Road Projects on Hold, for Now. Forbes.

https://www.forbes.com/sites/wadeshepard/2020/02/29/coronavirus-outbreak-puts-belt -and-road-projects-on-hold-for-now/amp/

Valero, J. (2020, March 3). Europe Ponders Economic Stimulus to Counter Coronavirus Impact. EURACTIV.

https://www.euractiv.com/section/economy-jobs/news/europe-ponders-economic-stim ulus-to-counter-coronavirus-impact/ 
Weerasekara, P. (2020, February 28). Coronavirus Slows China's Major Belt and Road Projects in Asia. REUTERS.

https://www.reuters.com/article/us-china-health-silkroad-idUSKBN20C0RF

Weinland, D., \& Liu, X. (2020, March 16). Chinese Economy Suffers Record Blow from Coronavirus. The Banker.

https://www.ft.com/content/318ae26c-6733-11ea-800d-da70cff6e4d3

Wright, F. (2020, February 12). Could Corona Virus Make China Stronger than Ever. Expat Guides. https://mp.weixin.qq.com/s/iD vefzwJtaDfxJjrVZqVQ

Yellinek, R. (2020, February 14). The Impact of China's Belt and Road Initiative on Central Asia and the South Caucasus. E-International Relations.

https://www.e-ir.info/2020/02/14/opinion-the-impact-of-chinas-belt-and-road-initiativ e-on-central-asia-and-the-south-caucasus/

Zhu, A. (2020, February 24). Which African Countries Are Most Vulnerable to the Coronavirus? The New Humanitarian.

https://www.thenewhumanitarian.org/news/2020/02/24/Coronavirus-Africa-risk-virus -Covid19-WHO-Lancet-study

Zogg, B. (2019). Cooperation, Co-Existence or Clash? China and Russia's Ambitions in Central Asia. The Diplomat.

https://thediplomat.com/2019/11/cooperation-co-existence-or-clash-china-and-russias -ambitions-in-central-asia/ 